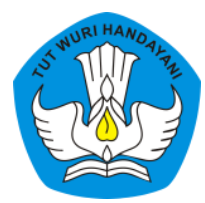

Page: 125-142

\title{
MENINGKATKAN KETERAMPILAN 4C DENGAN LITERASI DIGITAL DI SMP NEGERI 1 SIDOHARJO
}

\author{
Budi Sriyanto \\ Sekolah Menengah Pertama Negeri 1 Sidoharjo, Jawa Tengah, Indonesia \\ Contributor Email: budisriyanto@gmail.com
}

Received: Feb 13, 2021

Accepted: Mar 10, 2021

Published: Mar 30, 2021

Article Url: https://ojsdikdas.kemdikbud.go.id/index.php/didaktika/article/view/291

\begin{abstract}
This school action research aims to improve the 4C skills (critical thinking, creativity, communication, creativity and innovation, collaboration) of teachers with digital literacy application activities at SMP Negeri 1 Sidoharjo. The research setting was the subject teacher at SMP Negeri 1 Sidoharjo in the 2020/2021 school year. As research subjects are teachers, the principal at the junior high school as a researcher and assisted by an observer. This study consisted of 2 cycles. During the application of digital literacy activities, observations were made of teacher performance through observation, sociometry, and questionnaire sheets. Other findings during the course of the action were discussed between the researcher and the observer, equipped with data from the observations that were carried out by reflection in each cycle. The results of the study in cycle 1 and cycle 2 showed an increase in the $4 \mathrm{C}$ skills of teachers. The results of observations, sociometry, and questionnaires on the $4 \mathrm{C}$ skills of the teacher showed that in cycle 1 the average critical thinking score was $76 \%$, creativity $76 \%$, communication $75 \%$, creativity and innovation $76 \%, 76 \%$ collaboration on good criteria and in cycle 2 average critical thinking score $87 \%$, creativity $85 \%$, communication $86 \%$, creativity and innovation, collaboration $84 \%$ on very good criteria. Based on the results of the study, it can be concluded that the application of digital literacy can improve the $4 \mathrm{C}$ skills of teachers at SMP Negeri 1 Sidoharjo.
\end{abstract}

Keywords: Digital Literacy, Critical Thinking, Communicating, Creativity, Collaboration. 


\begin{abstract}
Abstrak
Penelitian Tindakan Sekolah ini bertujuan untuk meningkatkan keterampilan 4C (berpikir kritis, kreativitas, berkomunikasi, kreativitas dan inovasi, kolaborasi) guru dengan kegiatan penerapan literasi digital di SMP Negeri 1 Sidoharjo. Seting penelitian adalah di SMP Negeri 1 Sidoharjo tahun pelajaran 2020/2021. Sebagai subyek penelitian adalah guru, kepala sekolah di SMP tersebut sebagai peneliti dan dibantu seorang observer. Penelitian ini terdiri dari 2 siklus. Selama kegiatan penerapan literasi digital, dilakukan pengamatan terhadap kinerja guru melalui observasi, Sosiometri dan lembar angket. Temuan lain selama berlangsungnya tindakan didiskusikan antara peneliti dengan observer dilengkapi dengan data hasil pengamatan yang dilakukan refleksi pada setiap siklusnya. Hasil Penelitian pada siklus 1 dan siklus 2 menunjukkan adanya peningkatan keterampilan 4C guru. Hasil observasi, sosiometri, dan angket terhadap keterampilan 4C guru menunjukkan pada siklus 1 rata-rata skor berpikir kritis 76\%, kreativitas 76\%, berkomunikasi 75\%, kreativitas dan inovasi 76\%, kolaborasi 76\% pada kriteria baik dan pada siklus 2 rata-rata skor berpikir kritis 87\%, kreativitas 85\%, berkomunikasi 86\%, kreativitas dan inovasi, kolaborasi $84 \%$ pada kriteria sangat baik. Berdasarkan hasil penelitian dapat disimpulkan bahwa penerapan literasi digital dapat meningkatkan keterampilan 4C guru di SMP Negeri 1 Sidoharjo.
\end{abstract}

Kata Kunci: $\quad$ Literasi Digital, Berpikir Kritis, Berkomunikasi, Kreativitas, Kolaborasi.

\title{
A. Pendahuluan
}

Ilmu pengetahuan dan teknologi berkembang semakin pesat memasuki abad ke-21. Untuk menghadapi perkembangan ilmu pengetahuan dan teknologi tersebut dibutuhkan strategi tersendiri, baik di lingkungan pendidikan maupun dunia kerja saat ini. Diperlukan langkah konkret untuk mempersiapkan generasi saat ini supaya memiliki keterampilan baik soft skill maupun hard skill bagi siswa dari tingkat pendidikan sekolah dasar sampai perguruan tinggi. Abad ke-21 atau yang sering dikenal sebagai abad pengetahuan merupakan landasan utama untuk berbagai aspek kehidupan. Pembelajaran abad ke-21 lebih menekankan kemampuan siswa untuk berpikir kritis, mampu menghubungkan ilmu dengan dunia nyata, menguasai teknologi informasi, berkomunikasi, dan berkolaborasi.

Saat ini dunia, termasuk Indonesia, sedang menghadapi wabah Covid 19. Sesuai dengan surat edaran dari Kementerian Pendidikan dan 
Kebudayaan nomor 3 tahun 2020 Tentang Pelaksanaan Pembelajaran di Satuan Pendidikan di Masa Pandemi Covid 19 ini, kegiatan pembelajaran di satuan pembelajaran dilaksanakan secara daring untuk mencegah penyebaran Covid 19. Oleh karena itu, guru dituntut harus menguasai teknologi informasi.

Teknologi informasi pada pembelajaran daring di masa pandemi Covid 19 di abad ke-21 ini sangatlah penting dan harus dikuasai oleh siswa maupun guru di sekolah. Hal ini dikarenakan teknologi informasi telah memasuki berbagai dunia pendidikan. Perkembangan ilmu pengetahuan dan teknologi telah menghasilkan berbagai macam kemudahan di dalam proses belajar. Kemajuan teknologi informasi, komputer dan internet memberi banyak pilihan yang dapat menunjang kegiatan pembelajaran.

Teknologi informasi mempunyai banyak keunggulan tidak hanya pada faktor kecepatan memperoleh informasi tetapi juga fasilitas multimedia yang dapat membuat kegiatan pembelajaran menjadi lebih interaktif dan menarik. Selain itu, kemampuan untuk mendapatkan informasi dari berbagai media serta penggunaan media sosial bisa dimanfaatkan untuk mendapat berbagai informasi. Kemampuan untuk mengakses berbagai informasi dari banyak sumber dan cara memaknainya merupakan bagian dari literasi digital

SMP Negeri 1 Sidoharjo merupakan sekolah yang terletak di pinggiran Kabupaten Sragen yang saat ini melaksanakan pembelajaran secara daring. Warga sekolah, terutama guru SMP Negeri 1 Sidoharjo, dalam hal penguasaan dan pemanfaatan teknologi dan informasi dalam kegiatan pembelajaran secara daring belum optimal. Hal ini terbukti dalam penggunanan multimedia pembelajaran interaktif dalam pembelajaran daring masih jarang. Selain itu, pemanfaatan internet, HP, tablet, laptop dalam pembelajaran juga masih kurang.

Pemanfaatan teknologi dan informasi masih pada penggunaan media sosial pertemanan. Di sela-sela waktu longgar (waktu istirahat) para guru memanfaatkan waktu menggunakan $\mathrm{HP} /$ tablet untuk membuka 
media sosial pertemanan Facebook, WatshApp, Telegram, dan lain sebagainya. Ini menyebabkan berkurangnya komunikasi antarguru. Mereka lebih asyik dengan media sosial pertemanannya daripada berdiskusi dan berkolaborasi antarguru. Padahal berkomunikasi dan berkolaborasi merupakan bagian dari keterampilan 4C pada pembelajaran abad ke-21.

Rendahnya keterampilan 4C (communication, collaboration, critical thinking and problem solving, serta creative and inovative) antarguru perlu segera dicari solusinya. Salah satu solusi untuk meningkatkan keterampilan 4C guru adalah dengan penerapan literasi digital dalam kegiatan pembelajaran daring dari rumah. Literasi digital adalah kemampuan individu untuk menerapkan keterampilan dalam memanfaatkan perangkat digital sehingga kita dapat menemukan dan memilih informasi, berpikir kritis, berkreativitas, berkolaborasi bersama orang lain, berkomunikasi secara efektif (Hague \& Payton, 2010). Penerapan literasi digital dalam pembelajaran di antaranya dengan memanfaatkan video pembelajaran, multimedia pembelajaran interaktif, powerpoint maupun memanfaatkan akun belajar.id dan g suites.

Kegiatan penerapan literasi digital diawali dengan presentasi langkah-langkah kegiatan literasi digital (langkah-langkah membuat video pembelajaran, multimedia pembelajaran interaktif, pemanfaatan akun belajar.id dang suite) kepada para guru. Kegiatan selanjutnya, adalah diskusi dan kolaborasi para guru dalam kelompok mata pelajaran. Hasil diskusi dan kolaborasi tentang literasi digital para guru diterapkan dalam kegiatan pembelajaran daring dari rumah. Diharapkan penerapan literasi digital dalam kegiatan pembelajaran daring dari rumah dapat meningkatkan keterampilan 4C guru maupun siswa SMP Negeri 1 Sidoharjo.

Permasalahan yang diuraikan di atas perlu dipecahkan melalui tindakan sekolah dengan tujuan meningkatkan keterampilan 4C guru dengan kegiatan penerapan literasi digital di SMP Negeri 1 Sidoharjo. Caniago (2013: 8) menyebutkan bahwa literasi digital mencakup tentang pemahaman mesin pencari dan web. Dalam hal ini literasi digital juga dapat diartikan sebagai sikap dan pemahaman dalam mengomunikasikan 
pengetahuan dan informasi secara efektif dalam berbagai media dan format. Gilster (dalam Maulana, 2015: 3) memberi arti literasi digital sebagai kemampuan untuk menggunakan serta memahami informasi dalam berbagai bentuk dan dari banyak sumber ketika disajikan di dalam komputer. Karena itulah, pembelajaran literasi digital sangat diperlukan dalam dunia pendidikan.

Di sekolah, literasi digital dapat dimasukan ke dalam semua mata pelajaran seperti bahasa, Ilmu Pengetahuan Sosial (IPS), IPA, Matematika maupun komputer. Pada mata pelajaran bahasa misalnya, ada beberapa ketrampilan yang harus sebaiknya dikuasai siswa misalnya menyimak, membaca, dan menulis. Kalau dihubungkan dengan kegiatan literasi digital maka ketrampilan menyimak, membaca, dan menulis dapat dilakukan, baik dengan menggunakan media digital melalui komputer, internet maupun telepon pintar. Dengan penerapan literasi digital siswa diajak untuk dapat membedakan antara berita bohong dengan berita benar yang tersebar di media sosial maupun internet. Selain itu siswa dapat diberitahu tentang alamat-alamat situs yang bermanfaat untuk pembelajaran beserta cara penggunaannya.

Pembelajaran dengan memanfaatkan media digital juga melibatkan pembelajaran yang berhubungan dengan nilai-nilai universal yang harus ditaati setiap pengguna seperti kebebasan berekspresi, privasi, keberagaman budaya, hak intelektual, dan lain sebagainya. Dalam hal ini siswa akan lebih paham jika media digital bisa diibaratkan seperti sekeping mata uang: dalam satu sisi kebebasan informasi dan di sisi yang lain pelanggaran privasi. Kedua hal tersebut harus dipahami dan digunakan dalam batas-batas tertentu sehingga tidak merugikan diri sendiri dan pihak lain.

Pendidikan abad ked-21 merupakan pendidikan yang mengintegrasikan antara kecakapan pengetahuan, keterampilan, dan sikap, serta penguasaan teknologi informasi dan komunikasi. Kecakapan ini dikembangkan dengan beberapa model pembelajaran yang lebih menekankan 
pada aktivitas siswa sesuai dengan karakteristik kompetensi dan materi pembelajaran. Keterampilan yang diperlukan pada abad ke-21 ini merupakan keterampilan berpikir lebih tinggi (higher order thinking skills (HOTS)), keterampilan ini sangat diperlukan untuk mempersiapkan siswa dalam menghadapi tantangan global. Keterampilan 4C tersebut antara mencakup (1) keterampilan berpikir kritis dan pemecahan masalah, (2) keterampilan berkomunikasi (communication skills), (3) keterampilan kreativitas dan inovasi, dan (4) keterampilan kolaborasi. (Kemdikbud: 2017).

Penerapan keterampilan berpikir kritis dan pemecahan masalah, keterampilan berpikir kritis dan pemecahan masalah dalam proses pembelajaran antara lain dengan (a) Menggunakan beberapa macam tipe penalaran/pemikiran maupun alasan, baik induktif atau deduktif dengan tepat serta sesuai situasi; (b) Memahami interkoneksi antara satu konsep dengan konsep yang lain dalam suatu mata pelajaran, serta keterkaitan antarkonsep antara suatu mata pelajaran dengan mata pelajaran lainnya; (3) Melakukan penilaian serta memutuskan secara efektif dalam mengolah data dan menggunakan argumentasi; (4) Menguji hasil serta membangun koneksi antara informasi dan argumentasi; (5) Mengolah serta menginterpretasi informasi yang didapat melalui kesimpulan awal dan mengujinya lewat analisis terbaik; (6) Membuat solusi dari berbagai permasalahan nonrutin, baik dengan cara yang umum, maupun dengan caranya sendiri; Menggunakan kemampuan yang dimilikinya untuk berusaha menyelesaikan permasalahan; dan (8) Menyusun serta mengungkapkan, menganalisis, maupun menyelesaikan suatu masalah (Kemdikbud: 2017).

Keterampilan berkomunikasi (communication skills dalam proses pembelajaran antara lain mencakup (1) Memahami, mengelola, dan menciptakan komunikasi yang efektif dalam berbagai bentuk dan isi secara lisan, tulisan, dan multimedia (ICT Literacy); (2) Menggunakan kemampuan untuk mengutarakan ide-idenya, baik itu pada saat berdiskusi, di dalam dan di luar kelas, maupun tertuang pada tulisan; (3) Menggunakan bahasa lisan yang sesuai konten dan konteks pembicaraan 
dengan lawan bicara atau yang diajak berkomunikasi. Selain itu dalam komunikasi lisan diperlukan juga sikap untuk dapat mendengarkan, dan menghargai pendapat orang lain, selain pengetahuan terkait konten dan konteks pembicaraan; dan (4) Menggunakan alur pikir yang logis, terstruktur sesuai dengan kaidah yang berlaku (Kemdikbud: 2017).

Keterampilan kreativitas dan inovasi antara lain (1) Memiliki kemampuan dalam mengembangkan, melaksanakan, serta menyampaikan gagasan baru secara lisan maupun tulisan; (2) Bersikap terbuka serta responsif terhadap perspektif baru dan berbeda; (3) Mampu mengemukakan ide kreatif secara konseptual dan praktikal; (4) Menggunakan konsep maupun pengetahuannya dalam situasi baru dan berbeda, baik pada mata pelajaran terkait, antarmata pelajaran, atau dalam persoalan kontekstual; (5) Menggunakan kegagalan sebagai wahana pembelajaran; (6) Memiliki kemampuan dalam menciptakan kebaharuan berdasarkan pengetahuan awal yang dimiliki; dan (7) Mampu beradaptasi pada situasi baru serta memberikan kontribusi positif terhadap lingkungan (Kemdikbud: 2017).

Keterampilan kolaborasi dalam pembelajaran antara lain (1) Memiliki kemampuan dalam kerjasama berkelompok; (2) Beradaptasi dalam berbagai peran dan tanggung jawab, bekerja secara produktif dengan yang lain; (3) Memiliki empati dan menghormati perspektif berbeda, dan (4) Mampu berkompromi dengan anggota yang lain dalam kelompok demi tercapainya tujuan yang telah ditetapkan (Kemdikbud: 2017).

Berbagai penelitian telah dilakukan untuk meningkatkan kualitas dalam pembelajaran dengan menerapkan literasi digital di antaranya penelitian Hyland \& Kranzow (2011) menemukan bahwa penggunaan teknologi informasi seperti e-text dan e-library dapat membuat siswa merasa lebih baik karena memungkinkan mereka melakukan presentasi yang baik dan kreatif. Hasil penelitian lain yang dilakukan oleh Hague \& Payton (2010) menunjukkan bahwa siswa yang ekstensif serta intensif menggunakan teknologi dan informasi, cenderung mudah mengadopsi strategi pembelajaran dengan menggunakan berbagai alat teknologi dan informasi untuk mendukung kegiatan pembelajaran. 
Hasil penelitian Radovan (2014) menunjukkan bahwa literasi digital memberi pengaruh positif terhadap performa akademik dan berkontribusi terhadap penyelesaian tugas yang lebih efisien melalui bantuan perangkat lunak dan program komputer, seperti pengolah kata atau lembar kerja. Grant (2010) menyampaikan hasil penelitian terhadap penerapan literasi digital pada beberapa sekolah di Inggris yang lebih menekankan pada beberapa poin penting, misalnya memberikan ruang terhadap siswa untuk ikut terlibat dalam memilih subjek pelajaran, memicu kemandirian siswa dalam kegiatan pembelajaran serta meningkatkan kemampuan berkomunikasi antar siswa melalui penggunaan teknologi digital. Persamaan penelitian tindakan sekolah yang dilakukan dengan penelitian terdahulu adalah sama-sama menerapkan literasi digital dalam pembelajaran, tetapi penelitian ini lebih menekankan kepada peningkatan keterampilan $4 \mathrm{C}$ bagi guru.

\section{B. Metode}

Penelitian tindakan sekolah ini dilaksanakan pada guru yang mengajar di SMP Negeri 1 Sidoharjo Kabupaten Sragen. Penelitian tindakan sekolah ini dilaksanakan mulai dari tahapan persiapan, pelaksanaan, dan pembuatan laporan.

Subjek penelitian ini adalah guru SMP Negeri 1 Sidoharjo Kabupaten Sragen. Objek penelitian adalah kinerja dan aktivitas guru saat penelitian tindakan sekolah ini dilaksanakan.

Data yang diperlukan meliputi data keterlaksanaan kegiatan penerapan literasi digital, keterampilan $4 \mathrm{C}$ melalui penerapan literasi digital di SMP Negeri 1 Sidoharjo. Data diperoleh dari hasil observasi, pendokumentasian, pemberian angket, dan sosiometri.

Analisis data dilakukan pada waktu data diperoleh dari hasil tindakan oleh peneliti. Penelitian ini menggunakan analisis deskriptif. Data yang diperoleh dalam penelitian ini berupa data hasil observasi terhadap guru, angket keterampilan 4C, dan data hasil sosiometri. Teknik analisis data tersebut digunakan untuk mengetahui peningkatan keterampilan $4 \mathrm{C}$ guru setelah menggunakan literasi digital dalam pembelajaran. 


\section{Budi Sriyanto}

Data hasil angket dan sosiometri keterampilan 4C guru dianalisis dengan langkah-langkah sebagai berikut: Menghitung rata-rata hasil pilihan dan penilaian guru dalam kelompok, berdasar pedoman penyekoran yang telah dibuat, dihitung jumlah persentase skor keseluruhan. Persentase yang diperoleh kemudian dikualifikasi untuk menentukan seberapa besar tingkat kecakapan kolaborasi guru dalam mengikuti kegiatan penerapan literasi digital. Berikut tabel kualifikasi hasil persentase skor angket

Tabel. 1. Kategori Keterampilan 4C Guru

\begin{tabular}{ll}
\hline Rentang Skor & Kualifikasi \\
\hline $80,01 \%-100 \%$ & Sangat Baik \\
$60,01 \%-80 \%$ & Baik \\
$40,01 \%-60 \%$ & Sedang \\
$21,01 \%-40 \%$ & Kurang \\
$0-20 \%$ & Sangat Kurang \\
\hline
\end{tabular}

Validasi data dilakukan dengan teknik triangulasi untuk menjaga keabsahan data dalam penelitia. Triangulasi merupakan teknik pemeriksaaan keabsahan data yang memanfaatkan sesuatu yang lain di luar data itu untuk keperluan pengecekan atau sebagai pembanding. Triangulasi dilakukan dengan membandingkan data hasil observasi, angket, dan dokumentasi.

\section{Hasil dan Pembahasan}

Penelitian tindakan sekolah ini dilaksanakan dalam dua siklus. Masing-masing siklus terdiri dari 3 pertemuan (pertemuan pertama diskusi informasi langkah-langkah literasi digital; pertemuan kedua diskusi dan kolaborasi guru mata pelajaran dalam MGMP mata pelajaran dalam membuat multimedia pembelajaran interaktif dilanjutkan implementasi dalam pembelajaran daring sesuai jadwal; dan pertemuan ketiga diskusi informasi kelemahan dan kelebihan implementasi literasi digital dalam pembelajaran daring). Masing-masing siklus melalui empat langkah utama yaitu: perencanaan (planning), tindakan (acting), observasi (observing), dan refleksi(reflecting). 


\section{Hasil}

Tindakan-tindakan yang ditempuh pada siklus I adalah sebagai berikut. Pelaksanaan tindakan pada siklus 1 yang dilakukan oleh peneliti adalah menyusun lembar observasi keterampilan 4C, membuat media media pembelajaran, dan membuat media presentasi langkah-langkah penerapan literasi digital.

Pelaksanaan tindakan diawali dengan kegiatan presentasi langkah-langkah penerapan literasi digital kepada para guru mata pelajaran. Langkah selanjutnya, para guru diminta untuk bekerja dalam kelompok mata pelajaran, berdiskusi dan berkolaborasi untuk membuat multimedia pembelajaran interaktif, langkah-langkah membuat video pembelajaran dan pemanfaatan akun belajar.id serta g suite.

Hasil kegiatan diskusi dan kolaborasi antarguru dalam kelompok mata pelajaran kemudian diimplementasikan dalam kegiatan pembelajaran daring dari rumah. Selama kegiatan penerapan literasi digital dilakukan observasi keterampilan 4C guru dengan menggunakan lembar observasi. Di akhir kegiatan diskusi dan kolaborasi guru dalam kelompok mapel, dibagikan lembar sosiometri tentang keterampilan 4C guru.

Rangkuman hasil observasi keterampilan 4C guru setelah penerapan literasi digital siklus 1, disajikan pada tabel 2 berikut.

Tabel 2. Keterampilan 4C Guru setelah Penerapan Literasi Digital Siklus 1

\begin{tabular}{|c|c|c|c|c|c|}
\hline No & Mata Pelajaran & Communication & Collaboration & $\begin{array}{l}\text { Critical } \\
\text { Thinking }\end{array}$ & Creative \\
\hline 1 & $\begin{array}{l}\text { Pendidikan Agama } \\
\text { dan Budi Pekerti }\end{array}$ & $74 \%$ & $80 \%$ & $76 \%$ & $78 \%$ \\
\hline 2 & $\begin{array}{l}\text { Pendidikan Pancasila } \\
\text { dan Kewarganegaraan }\end{array}$ & $77 \%$ & $75 \%$ & $78 \%$ & $82 \%$ \\
\hline 3 & Bahasa Indonesia & $80 \%$ & $74 \%$ & $72 \%$ & $80 \%$ \\
\hline 4 & Matematika & $70 \%$ & $78 \%$ & $79 \%$ & $76 \%$ \\
\hline 5 & $\begin{array}{l}\text { Ilmu Pengetahuan } \\
\text { Alam }\end{array}$ & $78 \%$ & $70 \%$ & $71 \%$ & $75 \%$ \\
\hline 6 & $\begin{array}{l}\text { Ilmu Pengetahuan } \\
\text { Sosial }\end{array}$ & $76 \%$ & $73 \%$ & $84 \%$ & $73 \%$ \\
\hline 7 & Bahasa Inggris & $72 \%$ & $80 \%$ & $72 \%$ & $72 \%$ \\
\hline 8 & Seni Budaya & $79 \%$ & $75 \%$ & $78 \%$ & $79 \%$ \\
\hline
\end{tabular}


Budi Sriyanto

\begin{tabular}{llcccc}
9 & $\begin{array}{l}\text { Pendidikan Jasmani } \\
\text { Olahraga Kesehatan }\end{array}$ & $80 \%$ & $74 \%$ & $75 \%$ & $72 \%$ \\
10 & Prakarya & $74 \%$ & $78 \%$ & $78 \%$ & $79 \%$ \\
11 & Bahasa Jawa & $70 \%$ & $76 \%$ & $76 \%$ & $71 \%$ \\
12 & Bimbingan Konseling & $74 \%$ & $75 \%$ & $74 \%$ & $79 \%$ \\
& (BK) & & & \\
\hline & Rata-rata & $\mathbf{7 5 \%}$ & $\mathbf{7 6} \%$ & $\mathbf{7 6} \%$ & $\mathbf{7 6} \%$ \\
\hline
\end{tabular}

Tabel 2. menunjukkan bahwa keterampilan 4C para guru pada sebagian besar aspek setelah penerapan literasi digital siklus 1 berada pada kriteria baik. Ada beberapa aspek yang berada kriteria sangat baik yaitu pada mata pelajaran Pendidikan Pancasila dan Kewarganegaraan dengan keterampilan kreativitas guru persentase $82 \%$ dan mata pelajaran IPS dengan keterampilan berpikir kritis dengan persentase $84 \%$.

Setelah dilakukan refleksi berdasarkan hasil pengamatan, melalui diskusi antara kepala sekolah selaku peneliti dan observer disimpulkan bahwa kegiatan penerapan literasi digital siklus 1 sudah berjalan sesuai prosedur yang telah direncanakan. Walaupun demikian, masih terdapat beberapa permasalahan yang harus diselesaikan supaya pada siklus 2 dapat diperbaiki. Permasalahan tersebut adalah (a) Guru mata pelajaran masih kesulitan dalam membuat multimedia pembelajaran interaktif dan video pembelajaran dan (b) Dalam kegiatan diskusi kelompok, kerja sama antarguru belum terbangun dengan baik.

Pelaksanaan tindakan pada siklus 2 merupakan perbaikan Tindakan siklus 1 dengan cara memperbaiki media presentasi langkah-langkah penerapan literasi digital (langkah-langkah membuat video pembelajaran, multimedia pembelajaran interaktif, pemanfaatan akun belajar.id dan g suite). Untuk mengatasi kesulitan guru mata pelajaran dalam membuat pembelajaran dan multimedia pembelajaran interaktif dengan cara dibuatkan video tutorial tentang langkah-langkah penerapan literasi digital pembelajaran, multimedia pembelajaran interaktif. Untuk mengatasi kerja sama antarguru yang belum terbangun dengan baik dilakukan melalui kegiatan diskusi kelompok. Diharapkan kepala sekolah selaku peneliti saat 
penerapan literasi digital pada kegiatan diskusi selalu memotivasi guru agar aktif dalam kegiatan kelompok MGMP matapelajaran.

Pelaksanaan tindakan diawali dengan kegiatan presentasi langkah-langkah penerapan literasi digital (langkah-langkah membuat video pembelajaran, multimedia pembelajaran interaktif, pemanfaatan akun belajar.id dan g suite) kepada para guru mata pelajaran. Langkah selanjutnya meminta para guru untuk bekerja dalam kelompok mata pelajaran, berdiskusi dan berkolaborasi untuk membuat video pembelajaran, multimedia pembelajaran interaktif, pemanfaatan akun belajar.id dan g suite, kegiatan diskusi dan kolaborasi guru mata pelajaran dilengkapi dengan video tutorial tentang langkah-langkah membuat video pembelajaran, multimedia pembelajaran interaktif, pemanfaatan akun belajar.id dan $\mathrm{g}$ suite.

Hasil kegiatan diskusi dan kolaborasi antarguru dalam kelompok mata pelajaran kemudian diimplementasikan dalam kegiatan pembelajaran daring dari rumah.

Selama kegiatan penerapan literasi digital dilakukan observasi keterampilan 4C guru dengan menggunakan lembar observasi. Di akhir kegiatan diskusi dan kolaborasi guru dalam kelompok MGMP Mata Pelajaran, dibagikan lembar sosiometri tentang keterampilan 4C guru. Rangkuman hasil observasi keterampilan 4C guru setelah penerapan literasi digital siklus 2, disajikan pada tabel 3 berikut.

Tabel 3. Keterampilan 4C Guru setelah Penerapan Literasi Digital pada Siklus 2

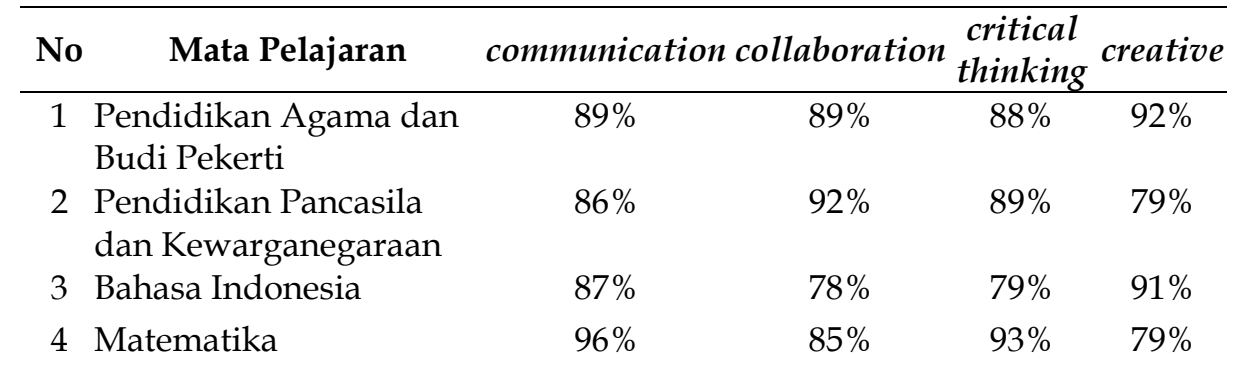




\section{Budi Sriyanto}

\begin{tabular}{lllll}
5 Ilmu Pengetahuan Alam & $92 \%$ & $76 \%$ & $79 \%$ & $81 \%$ \\
6 Ilmu Pengetahuan Sosial & $79 \%$ & $79 \%$ & $94 \%$ & $87 \%$ \\
7 Bahasa Inggris & $86 \%$ & $89 \%$ & $80 \%$ & $84 \%$ \\
8 Seni Budaya & $87 \%$ & $87 \%$ & $89 \%$ & $94 \%$ \\
9 Pendidikan Jasmani & $90 \%$ & $79 \%$ & $94 \%$ & $79 \%$ \\
Olahraga Kesehatan & & & & \\
10 Prakarya & $79 \%$ & $88 \%$ & $87 \%$ & $90 \%$ \\
11 Bahasa Jawa & $78 \%$ & $83 \%$ & $79 \%$ & $83 \%$ \\
12 Bimbingan Konseling & $85 \%$ & $86 \%$ & $91 \%$ & $84 \%$ \\
(BK) & & & & \\
\hline Rata-rata & $86 \%$ & $84 \%$ & $87 \%$ & $85 \%$ \\
\hline
\end{tabular}

Tabel 3 menunjukkan bahwa rata-rata semua aspek keterampilan 4C guru setelah penerapan literasi digital siklus 2 berada pada kriteria sangat baik, walaupun ada beberapa aspek berada pada kriteria baik

Refleksi dilakukan oleh kepala sekolah sebagai peneliti dan observer setelah pelaksanaan kegiatan penerapan literasi digital pada siklus 2 berakhir. Hasil refleksi menunjukkan bahwa pelaksanaan kegiatan penerapan literasi digital pada siklus 2 sudah berjalan sesuai prosedur yang telah direncanakan dengan semua aspek keterampilan $4 \mathrm{C}$ guru berada pada kriteria sangat baik.

\section{Pembahasan}

Berdasarkan hasil penelitian yang dilaksanakan di SMP Negeri 1 Sidoharjo tahun pelajaran 2020/2021, pada bagian ini akan dibahas mengenai hal pokok yang menjadi tujuan penelitian yaitu untuk mengetahui bagaimana penerapan literasi digital dapat meningkatkan keterampilan 4C guru.

Kegiatan literasi digital diawali dengan presentasi langkahlangkah penerapan literasi digital kepada para guru. Pada kegiatan ini terjadi interaksi antara kepala sekolah selaku peneliti dengan guru mata pelajaran, interaksi pada siklus 1 masih sedikit guru guru yang mengutarakan ide-idenya dalam rencana membuat video pembelajaran, multimedia pembelajaran interaktif, pemanfaatan akun belajar.id dan $g$ 
suite. Pada siklus 2 komunikasi yang terjalin cukup efektif, hal ini terlihat pada kemampuan bapak ibu guru dalam mengutarakan ide-idenya dalam rencana membuat membuat video pembelajaran dan multimedia pembelajaran interaktif, ini sesuai dengan penelitian dari Lunenburg (2010) yang menyatakan bahwa guru yang memiliki keterampilan komunikasi yang baik maka guru tersebut akan mampu menyampaikan ide-dengan kepada orang lain. Hasil penelitian ini sesuai dengan pendapat Patacsil (2017) dalam soft skill atau keterampilan lunak, keterampilan berkomunikasi ini berada pada urutan pertama dari seluruh keterampilan lunak yang ada.

Kegiatan selanjutnya adalah diskusi kelompok MGMP mata pelajaran. Pada kegiatan ini para guru bergabung dalam kelompok mata pelajaran untuk membuat video pembelajaran, multimedia pembelajaran interaktif, pemanfaatan akun belajar.id dan g suite. Pada siklus 1 masih ada beberapa guru yang masih kesulitan dalam membuatnya. Untuk mengatasi hal tersebut, pada siklus 2 peneliti membuat video tutorial tentang langkah-langkah membuat video pembelajaran, multimedia pembelajaran interaktif, pemanfaatan akun belajar.id dan g suite. Dengan dibuatkan video tutorial tersebut para guru semakin lancar dalam membuat video pembelajaran dan multimedia pembelajaran interaktif, kreativitas para guru meningkat. Terbukti dengan munculnya ide ide baru dalam membuat video pembelajaran dan multimedia pembelajaran interaktif. Ini sesuai dengan pendapat Leen (2014) yang menyatakan bahwa kreativitas berhubungan dengan keterampilan untuk menemukan sesuatu yang baru yang berbeda dari sebelumnya, lebih bersifat orisinil, memberikan solusi yang tepat pada setiap masalah, serta menemukan ide-ide baru yang lebih bervariasi, unik dan menarik.

Setelah diskusi kelompok mata pelajaran, dilanjutkan dengan penerapan literasi digital dalam kegiatan pembelajaran daring dari rumah. Peningkatan keterampilan 4C guru selama pelaksanaan tindakan penerapan literasi digital antara lain dapat dilihat peningkatan persentase dari hasil sosiometri pada grafik 1 di bawah ini. 


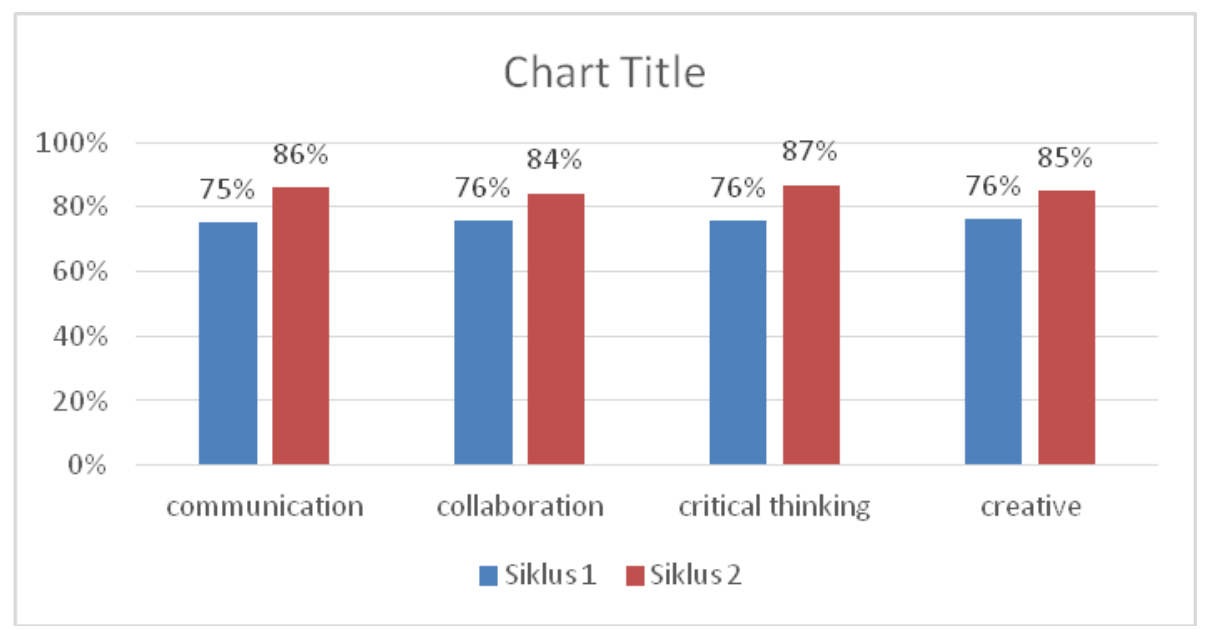

Grafik 1. Hasil Sosiometri Keterampilan 4C Guru pada Siklus 1 dan Siklus 2

Dari grafik 1 terlihat sekali bahwa dari keempat keterampilan abad ke-21 terjadi peningkatan persentase keterampilan berkomunikasi sebesar $11 \%$, keterampilan kolaborasi sebesar $8 \%$, berpikir kritis dan pemecahan masalah sebesar $11 \%$, keterampilan kreativitas dan inovasi sebesar 9\% dengan kategori sangat baik. Dari grafik tersebut diketahui bahwa penerapan literasi digital dapat meningkatkan keterampilan 4C guru. Hasil ini sesuai dengan penelitian Radovan (2014) yang menunjukkan bahwa literasi digital memberi pengaruh positif terhadap performa akademik. literasi digital dapat berkontribusi terhadap penyelesaian tugas yang lebih efisien melalui bantuan perangkat lunak dan program komputer, seperti pengolah kata atau lembar kerja.

Berdasarkan data hasil observasi, sosiometri dan angket diketahui bahwa penerapan literasi digital. Ini terlihat dari peningkatan keterampilan 4C guru dengan meningkatnya keterampilan 4C ini kreativitas dan inovasi guru semakin meningkat. Hal ini ditunjukkan dengan adanya ide-ide kreatif dari guru dan mengkomunikasikan ide-ide tersebut dan mengolaborasikan dengan rekan-rekannya sehingga menghasilkan karya/produk unggul untuk peningkatan prestasi siswa 
dan prestasi sekolah. Hal ini sesuai dengan pendapat Redhana (2019) yang menyatakan seseorang tidak maksimal menghasilkan suatu karya produk unggul sendirian, melainkan dihasilkan dengan berkolaborasi dengan berbagai pihak. Hasil penelitian ini belum merupakan hasil akhir dari penelitian tindakan sekolah yang dilakukan sehingga masih perlu adanya tindak lanjut melalui perencanaan yang lebih baik.

\section{Penutup}

Berdasarkan hasil penelitian tindakan sekolah yang dilakukan di SMP Negeri 1 Sidoharjo Kabupaten Sragen didapatkan hasil sebagai berikut: observasi, sosiometri dan angket terhadap keterampilan $4 \mathrm{C}$ guru menunjukkan pada siklus 1 rata-rata skor berpikir kritis 76\%, kreativitas $76 \%$, berkomunikasi $75 \%$, kreativitas dan inovasi $76 \%$, kolaborasi $76 \%$ pada kriteria baik dan pada siklus 2 rata-rata skor berpikir kritis $87 \%$, kreativitas $85 \%$, berkomunikasi $86 \%$, kreativitas dan inovasi, kolaborasi $84 \%$ pada kriteria sangat baik. Berdasarkan hasil penelitian dapat disimpulkan bahwa penerapan literasi digital dapat meningkatkan keterampilan 4C guru di SMP Negeri 1 Sidoharjo.

Berdasarkan hasil penelitian diajukan saran (1) Penelitian tindakan sekolah ini dapat ditindaklanjuti oleh peneliti atau kepala sekolah untuk meningkatkan mutu sekolah; (2) Para guru harus memperhatikan pemilihan materi pembelajaran yang sesuai dengan penerapan literasi digital untuk mendapatkan hasil penelitian yang maksimal; (3) Para gGuru mata pelajaran harus lebih kreatif dan inovatif dalam memanfaatkan teknologi informasi dalam membuat media pembelajaran interaktif agar hasil yang dicapai lebih meningkat.

\section{Ucapan Terima Kasih}

Terima kasih penulis ucapkan kepada para guru SMP Negeri 1 Sidoharjo atas bantuan dan peran aktifnya dalam penyelesaian karya tulis penelitian tindakan sekolah ini dan semua pihak yang tidak dapat disebutkan satu per satu atas bantuannya sehingga karya tulis dalam bentuk penelitian tindakan sekolah ini dapat terselesaikan. 
Budi Sriyanto

\section{Daftar Referensi}

Caniago, Junita Kahirani. (2013). Literasi Media dan Literasi Digital. http://junitakhairanicaniago.weebly.com/-uploads/1/8/4/6/18468290/makalah literasi media digital.pdf, diunduh tanggal 15 Januari 2021.

Hague, C \& Payton, S. (2010). Digital Literacy Across the Curriculum. Bristol: Futurelab.

Hyland, N \& Kranzow, J. (2011). Faculty And Student Views Of Using Digital Tools To Enhance Self-Directed Learning And Critical Thinking. International Journal of Self- Directed Learning Volume 8, Number 2.

Kemdikbud. (2017). Implementasi Pengembangan Kecakapan Abad 21 dalam Perencanaan Pelaksanaan Pembelajaran (RPP). Dit.PSMA Ditjen.Pendidikan Dasar dan Menengah, Kementerian Pendidikan dan Kebudayaan.

Maulana, Murad. (2015). Definisi, Manfaat, dan Elemen Penting Literasi Digital.http://www.muradmaulana.com/-2015/12/definisi-manfaat -danelemen-penting-literasi-digital.html, diunduh tanggal 15 Januari 2021.

Radovan, V. (2014). Digital Literacy as a Prerequisite for Achieving Good Academic Performance. Croatia : Ecil. 
Vol. 5, No. 1, Maret 2021 